\title{
Pengaruh Diskrepansi Harapan-Persepsi Pengembangan/ Pemeliharaan SDM Terhadap Kepuasan Kerja dan Komitmen Guru Sekolah Dasar
}

\author{
Dadang Dahlan \\ FPEB Universitas Pendidikan Indonesia
}

\begin{abstract}
Abstrak: Tujuan penelitian ini ialah untuk: 1 )mendeskripsikan diskrepansi harapan-persepsi guru SD terhadap pengembangan/pemeliharaan SDM; 2) menjelaskan pengaruh diskrepansi harapan-persepsi pengembangan/pemeliharaan SDM terhadap kepuasan kerja dan komitmen guru SD; 3) menjelaskan pengaruh kepuasan kerja terhadap komitmen guru SD. Populasi penelitian ini adalah guru SD Negeri di Kabupaten Bandung. Penarikan sampel dilakukan dengan teknik "multi stage random sampling", dengan ukuran sampel minimum sebanyak 322 orang guru. Metode penelitian yang digunakan adalah survei eksplanatori. Data dikumpulkan dengan menggunakan kuesioner, sedangkan teknik analisis data yang digunakan ialah analisis faktor konfirmatori dan analisis jalur dengan bantuan program LISREL. Hasil penelitian menunjukkan: 1) tinggi rendahnya kepuasan kerja guru SD secara langsung dipengaruhi besar kecilnya diskrepansi harapan-persepsi pengembangan/pemeliharaan SDM, sehingga semakin kecil tingkat diskrepansinya, semakin tinggi tingkat kepuasan kerja; 2) diskrepansi harapan-persepsi pengembangan/pemeliharaan SDM berpengaruh secara tidak langsung terhadap komitmen guru, sehingga semakin kecil tingkat diskrepansinya, semakin tinggi keterikatan guru terhadap pekerjaan dan organisasi sekolah tempatnya bekerja; dan 3) kepuasan kerja berpengaruh secara langsung terhadap komitmen guru, serta berpengaruh secara tidak langsung terhadap setiap faktor komitmen guru.
\end{abstract}

Kata kunci: pengembangan SDM, diskrepansi, kepuasan kerja, komitmen

\begin{abstract}
This study is aimed at: 1) describing the discrepancy between teacher's expectation and perception toward human resources development/maintenance; 2) explaining the influence of the discrepancy between teacher's expectation and perception toward human resources development/ maintenance for elementary teacher's job satisfaction and commitment; 3) explaining the influence of job satisfaction to teacher's commitment. The population of the study is state elementary school in Bandung regency. The technique sample is multi stage random sampling whose minimum size is 322 teachers. The method used is explanatory survey. The data is collected by using questionnaire while the data analysis technique is confirmatory factor and path analysis supported by LISREL program. The result of this study shows that: 1 ) the level of the teacher's job satisfaction is directly influenced by the magnitude of teacher's expectation-perception discrepancy toward human resources development/ maintenance, so that the lower discrepancy level is, the higher job satisfaction level; 2 ) the discrepancy between teacher's expectation and perception toward human resources development/maintenance indirectly influences teacher commitment as well so that the lower discrepancy is, the higher teacher commitment on work is; 3 ) the job satisfaction influences teacher commitment directly and each factor of teacher commitment indirectly.
\end{abstract}

Key words: human resources development, discrepancy, job satisfaction, and commitment

\section{Pendahuluan}

Fenomena yang muncul di dunia pendidikan, menunjukkan bahwa masih banyak permasalahan yang menyangkut guru di Indonesia, di antaranya berkisar pada persoalan "kurang memadainya kualifikasi dan kompetensi guru, kurangnya tingkat kesejahteraan guru, rendahnya etos kerja dan komitmen guru, serta kurangnya penghargaan masyarakat terhadap profesi guru" (Sidi, 2001:37). Status sosial ekonomi guru yang rendah telah mengundang apresiasi negatif masyarakat, karena guru dipandang sebagai masyarakat kelas tiga atau sama dengan kaum marjinal (Sayogyani, 2002). Hal ini tidak hanya terjadi di Indonesia, 
melainkan juga di negara-negara sedang berkembang lainnya. Di Liberia dan Somalia dilaporkan merosotnya kualitas pendidikan, ditandai dengan merosotnya moral kerja guru, banyaknya guru yang meninggalkan sekolah untuk bekerja di luar profesi kependidikan (teacher turnover). Hal ini merupakan pencerminan merosotnya kualitas kehidupan kerja guru (quality of teacher worklife) (Chapman, et.al., 1993:301). Ditinggalkannya profesi guru, antara lain dilatarbelakangi dengan kondisi gaji guru yang rendah, ketidakpuasan terhadap sistem yang ada, dan kondisi kerja yang buruk (Schargel,1994:18) .

Berbagai upaya pembaharuan pendidikan di Indonesia telah banyak dilakukan, antara lain melalui perbaikan sarana, kurikulum, sistem pengajaran, dsb. Namun, belum memberikan prioritas kepada unsur guru sebagai pelaksana, terutama dari segi kesejahteraannya. Karena itu, menurut Surya (2000:5) dalam kenyataannya guru tetap terabaikan dalam perwujudan keberdayaannya sebagai insan pendidikan. Guru lebih banyak memperoleh perlakuan sebagai objek administratif dan birokratis, sehingga keberdayaannya sebagai insan pendidikan selalu terpasung dan tidak berkembang. Manajemen sumber daya manusia belum memberikan kenyamanan bagi para guru dan selalu menimbulkan berbagai kendala dan masalah yang selalu dirasakan oleh para guru. Sebagai akibatnya, guru mengalami berbagai ketidakberdayaan, baik dalam kemampuan, karir, psikologis, maupun kesejahteraan (Jalal dan Supriadi, 2001:341).

Faktor mendasar yang terkait erat dengan kinerja profesional guru, adalah kepuasan kerja yang dilatarbelakangi oleh faktor-faktor imbal jasa, rasa aman, hubungan antarpribadi, kondisi lingkungan kerja, dan kesempatan untuk pengembangan diri (Surya, 2000:7). Kelima faktor ini belum dapat terwujud sepenuhnya dalam lingkungan kehidupan guru. Sebagai akibatnya, muncul sikap dan perilaku guru yang sering absen, meninggalkan tugas sebelum waktunya, sering mengeluh, mengelakkan sebagian dari tanggung jawab, dan merasa bosan dalam bekerja. Semua ini menunjukkan gejala kepuasan kerja yang rendah pada semua jenjang pendidikan tempat guru mengajar. Bahkan, seperti dikemukakan Sutjipto dkk. (dalam Jalal dan Supriadi, 2001:276), terdapat kecenderungan "semakin rendah jenjang pendidikan tempat guru-guru mengajar, semakin rendah pula tingkat kepuasannya".

Jika keadaan tersebut tidak berhasil diatasi maka akan berakibat buruk bagi kinerja dan profesi guru. Bahkan, bukan suatu hal yang mustahil akan banyak guru yang akan meninggalkan profesinya jika terdapat peluang untuk bekerja pada profesi lain. Seperti disinyalir oleh Surakhmad (2000:14) bahwa "banyak guru yang bertahan menjadi guru hanya karena tidak memperoleh alternatif kehidupan yang lain, guru sudah semakin tidak bangga terhadap profesi mereka". Sinyalemen Surakhmad, bukanlah tanpa dasar, sebab penelitian yang dilakukan BP3K (dalam Pidarta, 2004:119), memberikan gambaran bahwa banyak guru yang merasa tidak puas dengan kedudukan mereka karena tidak dihargai sebagaimana mestinya. Demikian pula kondisi dan peraturan yang tidak memungkinkan memberikan penghargaan kepada mereka yang berprestasi sehingga mengurangi motivasi mereka untuk tetap sebagai guru. Hal ini mencerminkan komitmen profesi yang rendah (derajat sejauh mana seorang guru loyal terhadap profesinya). Akibat dari kondisi ini, akan menurunkan minat generasi muda untuk memasuki profesi keguruan. Karena itu, agar profesi guru menjadi menarik, diperlukan model yang efektif untuk menarik sekaligus mengubah opini generasi muda tentang profesi guru (Kuzmic, 1994).

Dari latar belakang masalah, dapat diidentifikasi bahwa salah satu masalah pokok yang dihadapi guru-guru dewasa ini adalah merosotnya kualitas kehidupan kerja guru (quality of teacher worklife), atau merosotnya derajat pemenuhan kebutuhan manusia (human needs) dalam lingkungan organisasi (Dubrin, 1994:376). Hal ini ditandai oleh indikator kepuasan kerja dan komitmennya yang rendah. Secara kualitatif, hal ini antara lain ditandai dengan munculnya gejala : banyaknya keluhan, sering absen meninggalkan tugas, merasa bosan, kurangnya kerja keras, kurangnya dedikasi, berniat pindah tugas (sekolah) karena alasan ekonomi dll. Kepuasan dan komitmen yang rendah ini dilatarbelakangi oleh adanya diskrepansi harapan-persepsi guru mengenai sumber-sumber kepuasan kerja, baik intrinsik maupun ekstrinsik. Hal ini mencerminkan 
proses manajemen SDM yang belum terkelola secara optimal.

Terdapat sejumlah faktor yang harus diperhatikan dalam memperbaiki kondisi kualitas kehidupan kerja. Tiga faktor di antaranya ialah kompensasi (imbalan) finansial, pengembangan karir, dan kondisi kerja (lingkungan kerja). Ketiga faktor ini merupakan kajian pokok dari kualitas kehidupan kerja (Beatty dan Eric, 1992:395). Dilihat dari tingkat kepentingannya, kompensasi finansial (gaji) merupakan sumber kepuasan kerja yang paling penting, kesempatan promosi merupakan sumber kepuasan yang moderat, sedangkan kondisi kerja merupakan sumber kepuasan pada tingkat yang lebih bawah (Feldman dan Arnold, 1986). Ketiga faktor tersebut memiliki pengaruh positif terhadap kepuasan kerja dan komitmen guru.

Terpenuhinya harapan-harapan guru terhadap kompensasi, pengembangan karir, dan kondisi kerja akan mempengaruhi kualitas kehidupan kerjanya. Karena itu, pelaksanaan fungsi manajemen SDM harus mendukung ke arah terciptanya kondisi tersebut. Dalam kaitannya dengan hal tersebut, fungsi/aktivitas manajemen SDM yang perlu dioptimalkan adalah pengembangan, kompensasi, dan lingkungan kerja (Miner dan Mary Green Miner, 1987: 4).

Ketiga sumber kepuasan kerja tersebut diduga merupakan faktor yang dominan yang mempengaruhi kepuasan kerja dan komitmen guru di Indonesia, terutama untuk tingkat Pendidikan Dasar (Sekolah Dasar). Salah satu rekomendasi yang dikemukakan Kelompok Kerja Tenaga Kependidikan di Depdiknas adalah kenaikan gaji guru perlu dilakukan bersamaan dengan perbaikan pada aspek-aspek kesejahteraan lainnya yang meliputi "prosedur kenaikan pangkat, jaminan rasa aman secara fisik dan psikologis dalam menjalankan tugas, kondisi kerja, kepastian karier, dan pola hubungan yang lebih menonjolkan kolegalitas daripada pola hubungan hirarkies dalam lingkungan sekolah" (Jalal dan Supriadi, 2001:231). Masih terdapat kesenjangan (gap) antara harapan dan kenyataan dalam aspekaspek tersebut, sehingga tidak mengherankan jika harapan guru di Indonesia masih dominan pada kebutuhan fisik dan rasa aman, sekalipun asumsi harapan pegawai dalam manajemen SDM telah bergeser dari harapan rasa aman pada abad ke 20 menjadi harapan pengembangan diri (personal growth) pada abad ke 21 (Cascio, 1998).

Bertitik tolak dari identifikasi masalah tersebut maka dapat dirumuskan masalah (problem statement) sebagai berikut. Kualitas kehidupan kerja guru, atau derajat pemenuhan kebutuhannya untuk dapat tumbuh dan berkembang sebagai manusia yang bermartabat dalam profesinya cenderung masih rendah. Hal ini dapat diidentifikasi dari kepuasan kerja dan komitmennya yang masih rendah. Jika hal ini dibiarkan berlarut-larut maka kinerja guru dikhawatirkan akan lebih buruk dari kondisi sekarang, sehingga upaya peningkatan kualitas pendidikan tidak akan tercapai secara optimal. Karena itu, perlu diupayakan perbaikan kualitas kehidupan kerja guru melalui program-program pengembangan/ pemeliharaan SDM yang dapat meminimalkan diskrepansi harapan-persepsi guru dalam aspek kompensasi, pengembangan karir, dan kondisi kerja.

Selanjutnya, dapat dirumuskan pertanyaan penelitian (research questions) sebagai berikut. Apakah diskrepansi harapan-persepsi guru terhadap pengembangan/pemeliharaan SDM, merupakan faktor dominan yang menyebabkan rendahnya kepuasan kerja guru, sehingga mempengaruhi komitmennya terhadap profesi dan organisasi tempatnya bekerja ? Secara lebih rinci, dirumuskan sebagai berikut: 1) Bagaimanakah pengaruh diskrepansi harapan-persepsi pengembangan/pemeliharaan SDM terhadap kepuasan kerja guru Sekolah Dasar ? 2) Bagaimanakah pengaruh diskrepansi harapan-persepsi pengembangan/pemeliharaan SDM terhadap komitmen guru Sekolah Dasar? 3) Bagaimanakah pengaruh kepuasan kerja terhadap komitmen guru Sekolah Dasar? dan 4) Dilihat dari perbedaan jenis kelamin (gender), usia, masa kerja, dan tingkat pendidikan, pada kelompok mana model penelitian ini lebih efektif dalam menjelaskan fenomena kepuasan kerja dan komitmen guru Sekolah Dasar?

Tujuan penelitian ini adalah untuk memperoleh temuan mengenai: 1) Pengaruh diskrepansi harapan-persepsi pengembangan/pemeliharaan SDM terhadap kepuasan kerja guru Sekolah Dasar; 2) Pengaruh diskrepansi harapan-persepsi 
pengembangan/pemeliharaan SDM terhadap komitmen guru Sekolah Dasar; 3) Pengaruh kepuasan kerja terhadap komitmen guru Sekolah Dasar; dan 4) Pengaruh jenis kelamin (gender), usia, masa kerja, dan tingkat pendidikan terhadap kepuasan kerja dan komitmen guru Sekolah Dasar

\section{Kajian Literatur}

\section{Mutu Kehidupan Kerja (Quality of Work Life)}

Salah satu premis manajemen SDM adalah pandangan filosofis bahwa manusia merupakan aktiva organisasi yang dinamis, khas dan sangat penting (Sastradipoera, 2002:12). SDM diakui sebagai kunci suksesnya organisasi (Veithzal, 2004: 5) Karena dipandang sebagai aset penting maka tugas manajemen SDM adalah mengelola unsur manusia dengan segala potensi yang dimilikinya seefektif mungkin, sehingga dapat diperoleh SDM yang puas (satisfied) dan memuaskan (satisfactory) bagi organisasi. Karena itu, menurut pendekatan baru, manajemen SDM dapat dipandang sebagai pendekatan stratejik untuk mengelola aset paling berharga milik organisasi, yaitu orang-orang yang bekerja dalam organisasi,guna memberikan sumbangan terhadap pencapaian tujuan organisasi (Amstrong, 2003:5). Untuk mencapai tujuan tersebut, manajemen SDM berupaya mempengaruhi perilaku, sikap, dan kinerja karyawan, agar sesuai dengan harapan organisasi (Noe, R. et. al, 2003:5) .Untuk mencapai tujuan ini, perlu diciptakan dan dipelihara mutu atau kualitas kehidupan kerja yang menyenangkan

Terpeliharanya kualitas kehidupan kerja, ditandai dengan meningkatnya keterlibatan kerja, kepuasan kerja, dan komitmen pekerja, menurunnya stress kerja, dan berkurangnya tingkat kecelakaan. Kualitas kehidupan kerja merupakan hal yang krusial, bahkan menjadi salah satu sasaran manajemen SDM (Schuler et. al, 1992). Seperti dikatakan Benardin dan Russel (1993: 520) bahwa kualitas kehidupan kerja yang baik dalam suatu organisasi perlu diciptakan dan ditingkatkan terus menerus, karena kualitas kehidupan kerja yang baik akan dapat meningkatkan kepuasan kerja, harga diri, motivasi, keterlibatan, dan komitmen individu yang berkenaan dengan kehidupan mereka dalam bekerja. Peningkatan kualitas kehidupan kerja ini antara lain dapat dilakukan melalui programprogram: 1) kondisi kerja, yang mencakup keamanan, kesehatan, dan lingkungan fisik; 2) keadilan dalam pemberian kompensasi; 3 ) manajemen partisipasi (Bowin \& Harvey, 1996). Sejalan dengan pendapat tersebut, Lawler (1992: 50) menyatakan pula bahwa banyak aspek dari manajemen SDM yang memberikan sumbangan pada kehidupan kerja yang berkualitas seperti pelatihan dan pengembangan, rancangan jabatan yang memungkinkan karyawan menggunakan keterampilan mereka, praktik manajemen yang memberikan karyawan tanggung jawab untuk mengambil keputusan penting, sistem promosi dan seleksi yang menjamin perlakuan yang sama dan adil, lingkungan fisik dan psikologis yang sehat, dan pekerjaan yang diorganisir dalam kelompok. Praktek-praktek semacam ini meningkatkan komitmen dan kepuasan kerja karyawan.

\section{Komitmen dan Kepuasan Kerja}

Komitmen merupakan hal yang krusial dalam manajemen SDM, sebab berdampak cukup besar terhadap organisasi. Pencapaian misi/tujuan organisasi hanya mungkin bila dapat menjamin komitmen dari pekerjanya dan dengan kreativitas yang tak terkurangi, komitmen akan mampu meningkatkan kualitas dan produktivitas (Snyder et.al, 1994).

Untuk mempertahankan/memelihara pekerja yang memiliki komitmen yang tinggi, maka organisasi harus dapat memenuhi seperangkat kebutuhan (needs) karyawannya.Tuntutan karyawan terhadap organisasi menyangkut eksistensi mereka dalam organisasi, seperti gaji, penghargaan, perlindungan, lingkungan kerja yang sehat, jaminan sosial, dll. Dalam perspektif pelayanan kualitas total (TQS), kepada karyawan harus diberikan "total human reward" sebagai bentuk kualitas pelayanan internal sehingga tercipta lingkungan internal yang kondusif (Tjiptono, 1997:125). Dalam terminologi manajemen SDM, lingkungan internal yang kondusif ini mencerminkan kualitas kehidupan kerja (quality of work life) yang menyenangkan.

Indikator terpenuhi kebutuhan karyawan adalah kepuasan kerja (job satisfaction). Indikator ini merupakan tujuan utama organisasi yang kedua selain produktivitas (Gaffar, 1987:144). 
Kepuasan kerja memiliki peranan yang penting, sebab pekerja yang puas merupakan prakondisi bagi meningkatnya produktivitas, daya tanggap, mutu, dan layanan pelanggan (Kaplan dan Norton, 2000:112). Demikian pula, kepuasan kerja akan meningkatkan keterlibatan kerja dan komitmen organisasi (Robbins, 1996). Dalam hal ini, kepuasan kerja yang rendah cenderung mengakibatkan komitmen pekerja yang rendah pula, sebaliknya kepuasan kerja yang tinggi cenderung mengakibatkan komitmen yang tinggi pula. Begitu pentingnya konsep kepuasan kerja, sehingga ditempatkan sebagai konsep sentral (a central concept) di dalam pekerjaan dan psikologi organisasi (Dorman dan Zape, 2001). Kepuasan dan komitmen (loyalitas) pekerja dianggap sebagai kunci penggerak ke arah produktivitas dan efisiensi (Silvestro, Rhian, 2002). Dalam perspektif manajemen kualitas total (TQM), kemampuan organisasi merespons kebutuhan pelanggan secara efektif, ditentukan oleh karyawannya yang puas dan loyal. Ditegaskan oleh Silvestro (2002:42) bahwa "employee satisfaction and loyalty are seen as critical to the capability of service organizations to respons effectively to customer needs". Memperlakukan karyawan dengan baik, akan membuat mereka puas, selanjutnya karyawan yang puas tersebut akan memberikan pelayanan yang baik terhadap pelanggan.

Kepuasan kerja yang tinggi merupakan ciri organisasi yang dikelola dengan baik dan pada dasarnya merupakan hasil manajemen perilaku yang efektif (Fieldman dan Arnold H.J, 1986). Karena itu, fungsi manajemen SDM dalam organisasi diperlukan untuk menciptakan dan memelihara kualitas kehidupan kerja (quality of work life) yang menyenangkan, sehingga dapat menimbulkan kepuasan dan motivasi kerja (Werther dan Davis, 1996:501). Dalam hal ini proses manajemen SDM yang terkelola secara profesional, akan menghasilkan SDM yang kompeten, bermotivasi tinggi, memiliki komitmen dan kepuasan kerja, yang akhirnya akan berpengaruh terhadap produktivitas dan perkembangan organisasi.

Dalam kaitannya dengan variabel-variabel penelitian ini, dapat dijelaskan bahwa pengelolaan yang efektif dalam pengembangan karir (fungsi pengembangan SDM), kompensasi dan kondisi kerja (fungsi pemeliharaan SDM) akan menghasilkan kepuasan kerja dan komitmen karyawan. Hal ini sejalan dengan pendapat Lawler (dalam Steers, 1987) yang menyatakan bahwa manajemen SDM memiliki peranan yang penting dalam meningkatkan komitmen karyawan terhadap organisasi melalui keterlibatan kerja yang tinggi. Menurut Lawler, ciri-ciri organisasi yang memiliki keterlibatan kerja yang tinggi, antara lain: 1) Penggajian (kompensasi) karyawan tidak didasarkan pada skor jabatan, tetapi berdasarkan keterampilan dari masing-masing karyawan; 2) Organisasi merencanakan dan melakukan pelatihan, perencanaan karir, dan pengembangan pribadi karyawan; dan 3) Organisasi mengatur tata ruang kerja sedemikian rupa, sehingga setiap karyawan merasa nyaman dalam lingkungan kerja.

\section{Faktor-faktor yang mempengaruhi Kepuasan Kerja dan Komitmen Guru}

Bertitik tolak dari kerangka teori tersebut di atas, pemberdayaan SDM guru, seyogyanya diarahkan pula pada sasaran: 1) peningkatan kapabilitas (kemampuan/kompetensi); 2) peningkatan komitmen, baik komitmen profesi, komitmen organisasi, maupun komitmen mengajar (teaching commitment). Komitmen guru dapat dianggap penting, sebab temuan terdahulu menunjukkan bahwa komitmen guru yang rendah akan menurunkan prestasi belajar siswa (Firestone dan Pennel, 1993). Komitmen guru yang tinggi ditandai dengan kuatnya ikatan psikologis dengan profesi, sekolah, siswa, dan mata pelajaran yang dibinanya.

Untuk meningkatkan dan memelihara komitmen guru, perlu diperhatikan kepuasan kerjanya. Dalam hal ini, terdapat sejumlah faktor sebagai unsur pembentuk kepuasan kerja,baik faktor intrinsik maupun ekstrinsik. Tiga faktor di antaranya adalah kompensasi (imbalan), pengembangan karir, dan kondisi kerja (lingkungan kerja). Gaji merupakan bentuk imbalan finansial yang diberikan kepada karyawan berdasarkan periode tertentu. Karyawan biasanya mengharapkan gaji yang adil dan layak sesuai dengan tuntutan kebutuhan mereka. Karena itu, penerapan sistem kompensasi yang adil dan dapat memenuhi 
kebutuhan pekerja dalam suatu organisasi, akan meningkat-kan kepuasan kerja, motivasi kerja, dan produk-tivitas kerja (Mangkunegara, 1995:84). Pada gilirannya, sistem kompensasi yang adil juga dapat meningkatkan komitmen, sebab mereka merasa diperlakukan secara adil (Susanto, 1997:65).

Pengembangan karir merupakan aktivitas kepegawaian yang membantu pegawai-pegawai merencanakan karir masa depan mereka di perusahaan agar pegawai yang bersangkutan dapat mengembangkan diri mereka secara maksimum (Mangkunegara, 1995:77). Sistem pengembangan karir yang efektif ini akan meningkatkan motivasi, kepuasan kerja dan produktivitas kerja karyawan (Bowin dan Harvey, 1996 ). Di sisi lain, akan meningkatkan komitmen, sebab dengan adanya kesempatan untuk berkembang dan untuk meningkatkan karir secara jelas, karyawan akan merasa lebih aman berada dalam organisasi, dan dengan sendirinya akan membentuk keterikatan psikologis (Susanto, 1997:65).

Di samping kompensasi finansial dan pengembangan karir, karyawan pun sangat dipengaruhi oleh kondisi kerja (lingkungan kerja) ini dapat berupa kondisi fisik seperti gedung tempat bekerja, penerangan, ventilasi, kebisingan, dll. Dalam hal ini perbaikan lingkungan kerja akan meningkatkan kualitas kehidupan kerja dan produktivitas (Schuler, 1992). Semua faktor lingkungan kerja ini dapat mempengaruhi kepuasan kerja karyawan, yang pada gilirannya akan mempengaruhi komitmen mereka terhadap profesi dan organisasi sebab komitmen karyawan ini dipengaruhi pula oleh lingkungan kerja yang sesuai dengan kebutuhan dan kesehatan, serta tersedianya fasilitas kerja yang mendukung (Susanto, 1997).

Selain faktor-faktor tersebut di atas, kepuasan kerja dan komitmen dipengaruhi pula oleh faktor individu (pribadi) yang melekat pada diri karyawan, seperti usia, jenis kelamin (gender) masa kerja, jenjang pekerjaan, dan tingkat pendidikan (Handoko, 1996:198).

\section{Hipotesis}

Bertitik tolak dari kerangka pemikiran dapat dirumuskan hipotesis yang merupakan dugaan sementara terhadap masalah yang diteliti, yang selanjutnya akan diuji kebenarannya berdasarkan hasil pengolahan data. Hipotesis penelitian dirumuskan sebagai berikut: 1) Diskrepansi harapan-persepsi guru SD terhadap pengembangan/pemeliharaan SDM berpengaruh negatif terhadap kepuasan kerjanya; 2) Diskrepansi harapan-persepsi guru SD terhadap pengembangan/pemeliharaan SDM berpengaruh negatif terhadap komitmennya terhadap profesi dan organisasi; (3) Kepuasan kerja guru SD berpengaruh positif terhadap komitmennya terhadap profesi dan organisasi; dan (4) Jenis kelamin (gender), usia, masa kerja, dan tingkat pendidikan berpengaruh terhadap kepuasan kerja dan komitmen guru SD.

\section{Metodologi Penelitian}

Sesuai dengan kerangka penelitian, terdapat tiga variabel yang diteliti sebagai objek penelitian ini, yaitu diskrepansi harapan-persepsi pengembangan/pemeliharaan SDM (dengan subvariabel kompensasi, pengembangan karir, dan kondisi kerja), kepuasan kerja, dan komitmen. Dalam penelitian ini, variabel bebasnya adalah diskrepansi harapan-persepsi pengembangan/ pemeliharaan SDM, sedangkan variabel tergantungnya adalah kepuasan kerja dan komitmen. Karena variabel kepuasan kerja merupakan variabel bebas bagi komitmen maka variabel ini ditempatkan sebagai variabel moderator. Subjek penelitiannya adalah guru SD Negeri di Kabupaten Bandung, dengan unit observasi dan analisisnya pada tingkat individu. Pengumpulan data dalam rangka penelitian ini dilakukan pada bulan Januari sampai April tahun 2005.

\section{Pendekatan Penelitian}

Berdasarkan tujuan penelitian yang telah dirumuskan, bahwa penelitian ini selain bertujuan untuk mengetahui diskrepansi harapan-persepsi para guru terhadap fungsi pengembangan/ pemeliharaan SDM, juga untuk mengetahui pengaruh variabel-variabel tersebut terhadap kepuasan kerja dan komitmennya (komitmen profesi maupun komitmen organisasi). Karena itu, dilihat dari tingkat eksplanasinya, penelitian yang dilakukan ini termasuk jenis penelitian deskriptifanalitik (untuk mendeskripsikan variabel yang 
diamati dan untuk menguji hubungan variabelvariabel yang diamati). Karena tujuannya difokuskan untuk menguji hubungan kausal antarvariabel, penelitian ini dikategorikan juga sebagai penelitian eksplanatori yang bersifat noneksperimental.

\section{Populasi dan Sampel}

Populasi penelitian ini adalah guru Sekolah Dasar Negeri di kabupaten Bandung sebanyak 12.905 orang yang tersebar di 42 kecamatan dan 2.171 sekolah (Rangkuman Data Sekolah Dasar Kabupaten Bandung, 2004).

Sesuai dengan karakteristik sebaran populasi, pengambilan sampel dilakukan dengan teknik "multi stage random sampling" yakni penarikan sampel secara random yang dilakukan melalui tiga tahap, yaitu: 1) menentukan jumlah kecamatan yang menjadi sampel wilayah; 2) menentukan jumlah sekolah dari setiap kecamatan yang terpilih sebagai sampel; 3) menentukan jumlah guru dari setiap sekolah yang terpilih sebagai sampel. Dengan teknik ini ditetapkan ukuran sampel 322 orang yang mewakili 5 area atau wilayah di kabupaten Bandung.

\section{Teknik Pengumpulan Data}

Sesuai dengan pendekatan penelitian yang digunakan maka teknik pengumpulan data yang digunakan dalam penelitian ini adalah kuesioner (angket). Seperti ditegaskan oleh Sevilla et.al (1993 : 200) "kuesioner sangat efektif digunakan dalam pendekatan survey". Alasan lainnya, penggunaan kuesioner dalam penelitian ini dianggap efektif, sebab responden penelitian ini adalah guru-guru yang minimal berpendidikan sederajat SLTA, sehingga mudah membaca dan memahami pertanyaan/pernyataan yang tercantum dalam kuesioner.

Untuk menjaring data sesuai dengan variabel yang diteliti, dikembangkan lima macam kuesioner, yaitu: 1) kuesioner skala harapan dan persepsi kompensasi (SHPK); 2) kuesioner skala harapan dan persepsi pengembangan karir (SHPP); 3) kuesioner skala harapan dan persepsi kondisi kerja (SHPKK); 4) kuesioner skala kepuasan kerja $(\mathrm{SKK}) ; 5)$ kuesioner skala komitmen guru (SKG).

\section{Teknik Analisis Data}

Sesuai dengan perumusan masalah, tujuan penelitian, dan perumusan hipotesis, maka teknis analisis data yang dipergunakan dalam penelitian ini adalah analisis multivariat, yaitu analisis faktor konfirmatori (confirmatory factor analysis) dan analisis jalur (path analysis).

Analisis multivariat yang digunakan terdiri atas dua teknik analisis. Pada tahap pertama, digunakan analisis faktor konfirmatori Hal ini dilakukan untuk mengkonfirmasi struktur ketepatan model yang dibangun berdasarkan kerangka teori dengan data empirik hasil pengamatan. Sebelum dilakukan analisis faktor konfirmatori, terlebih dahulu dilakukan pengujian asumsi statistik untuk memenuhi persayaratan penggunaan model SEM

Pada tahap kedua, digunakan analisis jalur (path analysis). Tujuan utama penelitian ini adalah menguji hubungan kausalitas antarvariabel laten. Hipotesis dalam model tersebut, dapat digambarkan dalam kerangka analisis SEM, yang divisualisasikan pada Gambar 1.

Pada tahap ketiga, dilibatkan variabel kontrol ke dalam model penelitian. Variabel kontrol yang dimaksud meliputi jenis kelamin (gender), usia, masa kerja, dan latar belakang pendidikan. Dilibatkannya variabel kontrol (multigroup sample) ke dalam model, dimaksudkan untuk dapat memberikan penjelasan secara lebih rinci mengenai keberlakukan model penelitian.

\section{Hasil Penelitian dan Bahasan}

Untuk menguji hipotesis penelitian, telah dirumuskan rancangan pengujian hipotesis. Melalui program LISREL 8,30 pengujian hipotesis penelitian dilakukan secara simultan. Hasil perhitungan statistik program disajikan pada Gambar 2 dan 3.

Berdasarkan hasil pengujian hipotesis, sebagaimana divisualisasikan pada Gambar 2 dan 3 (Model I) diperoleh suatu simpulan bahwa hipotesis penelitian pertama, dan hipotesis ketiga dapat diterima,sedangkan untuk hipotesis penelitian kedua, tidak dapat diterima, sebab terdapat koefisien jalur yang tidak signifikan, yaitu dari Diskrepansi ke Komitmen. Dengan demikian, model perlu diperbaiki dengan metode "trimming", 


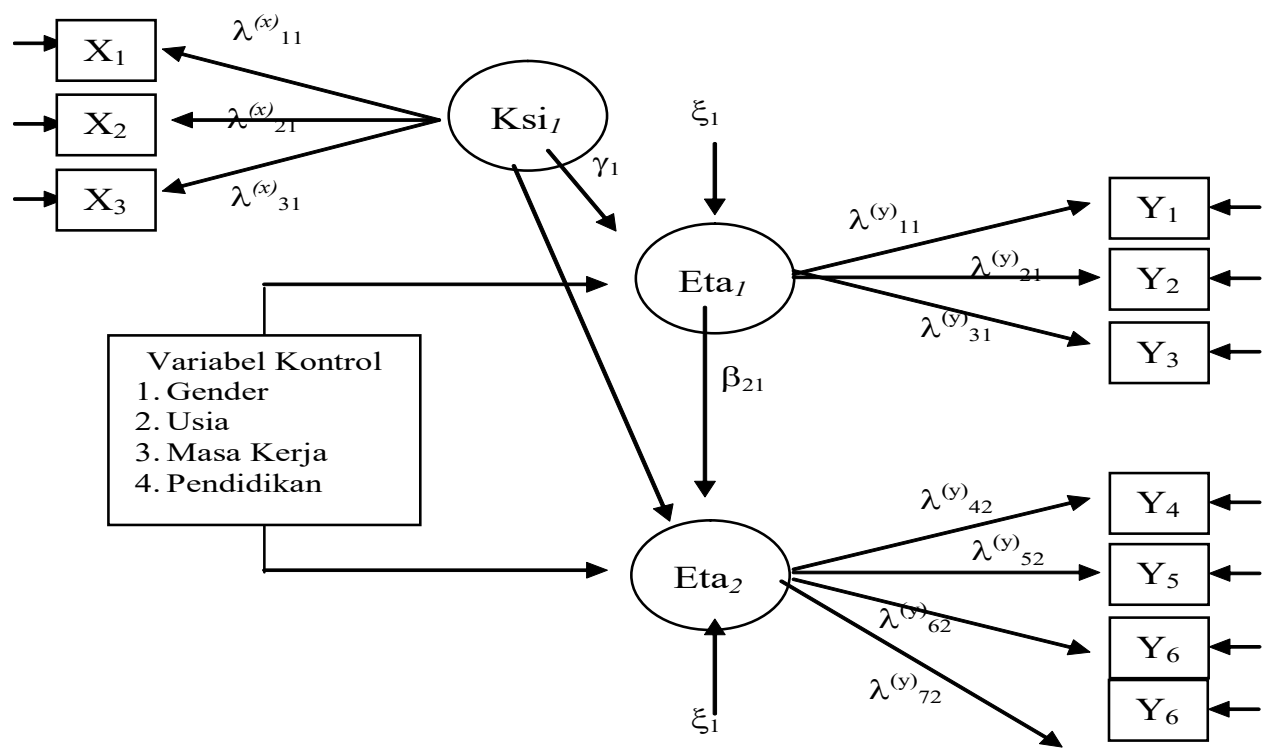

Gambar 1. Diagram Jalur Lengkap Hipotesis Penelitian

Keterangan :

Ksi = Diskrepansi harapan-persepsi pengem bangan/pemeliharaan SDM

Eta1 = Kepuasan kerja

Eta2 $=$ Komitmen guru

$\mathrm{X} 1=$ Diskrepansi harapan-persepsi kompensasi

$\mathrm{X} 2=$ Diskrepansi harapan-persepsi pengem bangan karir

X3 = Diskrepansi harapan-persepsi kondisi kerja
$\mathrm{Y} 1=$ Pemotivasian (motivators)

$\mathrm{Y} 2=$ Ambients

Y3 = Pemeliharaan (hygienes)

Y4 = Komitmen profesi

Y5 = Komitmen afektif

Y6 = Komitmen rasional

Y7 = Komitmen normatif

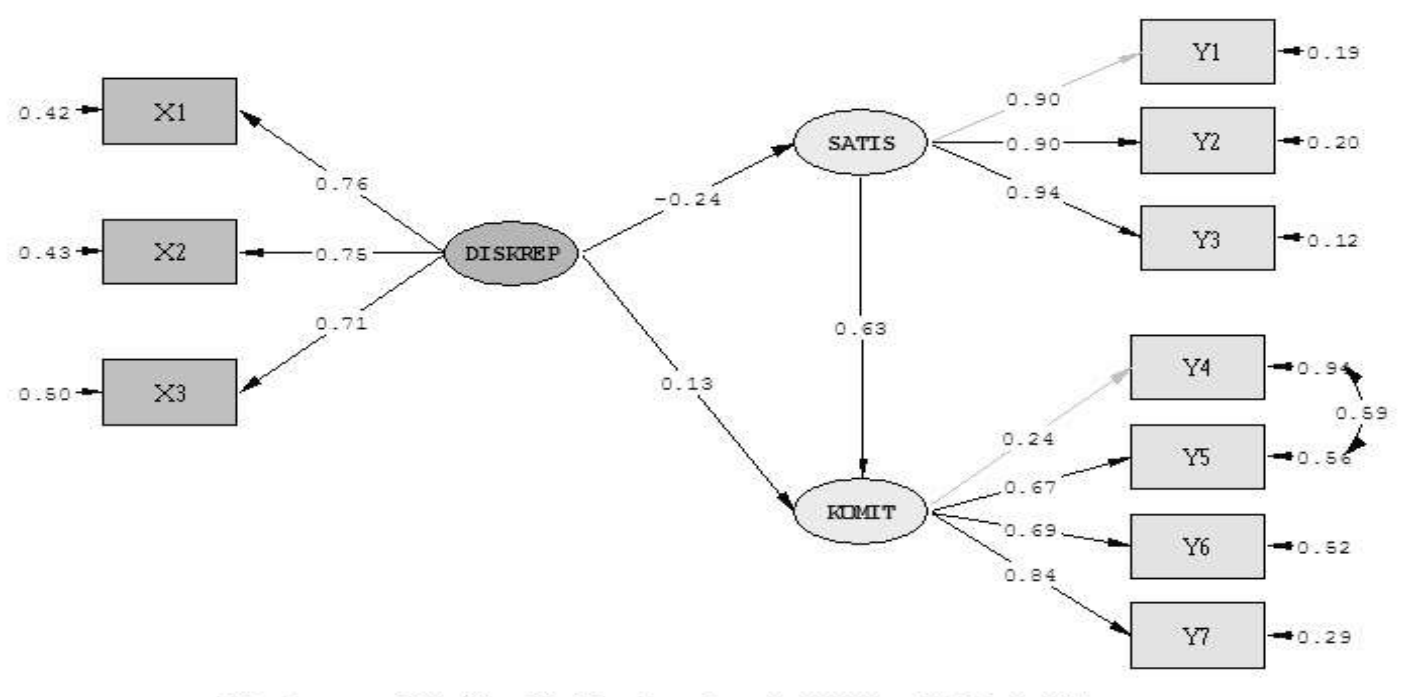

Chi-Square $=120.69$, df $=31, \mathrm{~F}-\mathrm{value}=0.00000, \mathrm{RMSEA}=0.095$

Gambar 2. Estimasi Persamaan Struktural Model Studi Mutu Kehidupan Kerja Guru SD (Model I)

yaitu dengan cara mendrop jalur yang koefisiennya tidak signifikan. Hasil perbaikan model I, disajikan pada Tabel 1 dan Gambar 4

Tabel 1 menginformasikan bahwa 1) besarnya koefisien jalur variabel laten diskrepansi harapan-persepsi pengembangan SDM terhadap variabel laten kepuasan kerja sebesar $-0,24$ dengan nilai kesalahan standar 0,066 dan t hitung 3,65 (signifikan dalam taraf kepercayaan 0,05); 2) besarnya koefisien jalur variabel laten kepuasan kerja terhadap variabel laten komitmen sebesar 0,56 dengan nilai kesalahan standar 


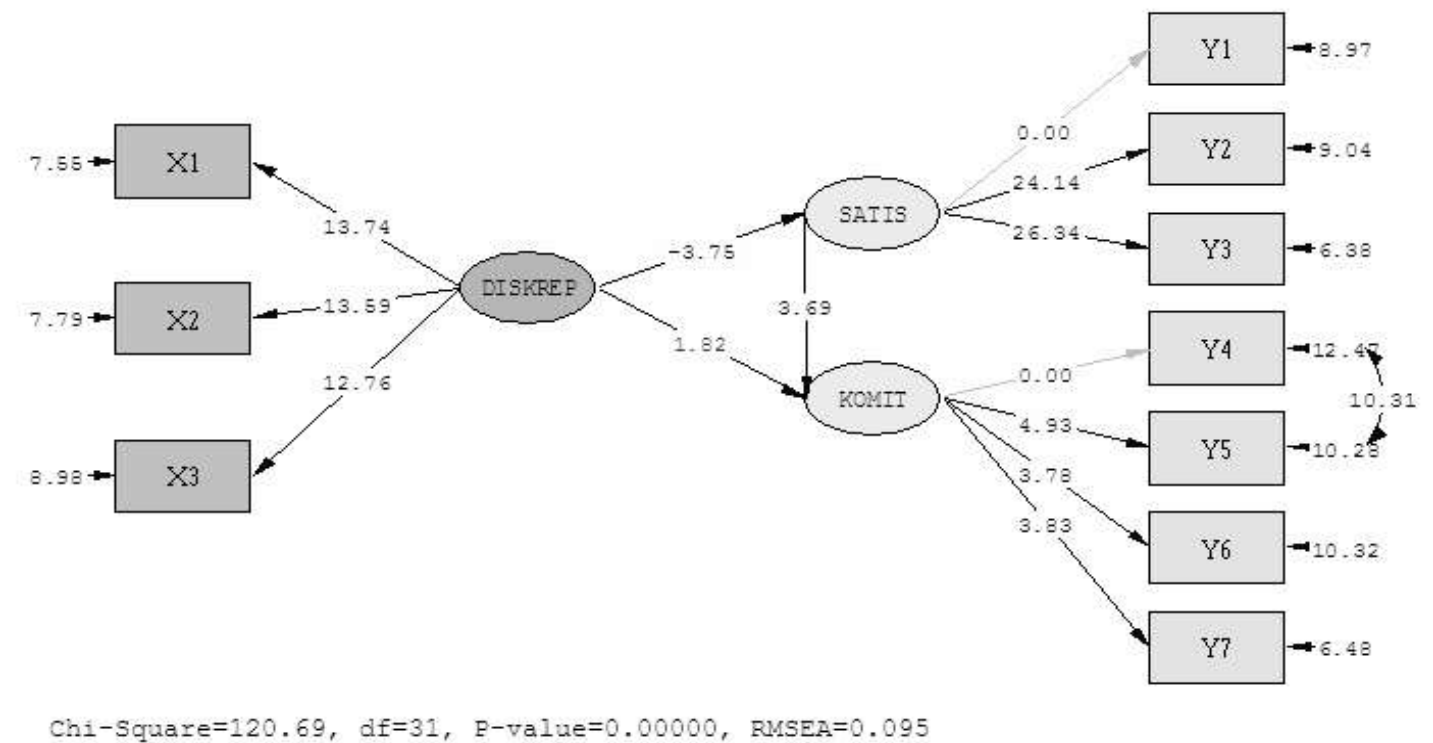

Gambar 3. Statistik t hitung Parameter Model Studi Mutu Kehidupan Kerja

sebesar 0,069 dan t hitung 9,21 (signifikan dalam taraf kepercayaan 0,05 ).

Tabel 1. Ringkasan Hasil Pengujian Hipotesis Model Studi Mutu Kehidupan Kerja Guru (Model II) $(n=322)$

\begin{tabular}{|l|c|c|c|c|c|}
\hline $\begin{array}{c}\text { Hubungan } \\
\text { Variabel } \\
\text { yang diuji }\end{array}$ & $\begin{array}{c}\text { Taksiran } \\
\text { Parameter } \\
\text { koefisien } \\
\text { jalur }\end{array}$ & $\begin{array}{c}\text { Standar } \\
\text { error }\end{array}$ & $\begin{array}{c}\text { Nilai t } \\
\text { hitung }\end{array}$ & Hasil Uji & $\mathrm{R}^{2}$ \\
\hline $\begin{array}{l}\text { Diskrep- } \\
\text { Kepuasan }\end{array}$ & $-0,24$ & 0.066 & 3,65 & Sign. & 0,057 \\
\hline $\begin{array}{l}\text { Kepuasan- } \\
\text { Komitmen }\end{array}$ & 0,56 & 0.069 & 8,21 & Sign & 0,32 \\
\hline
\end{tabular}

Hasil pengujian model menunjukkan bahwa hampir semua ukuran goodness of fit, yakni GFI, NFI, NNFI, CFI lebih besar dari 0,90. Hal ini menunjukkan bahwa model persamaan struktural pengaruh diskrepansi pengembangan SDM terhadap kepuasan kerja dan komitmen, fit dengan data.

Hasil pengujian hipotesis pertama, menunjukkan bahwa diskrepansi harapan-persepsi pengembangan/pemeliharaan SDM berpengaruh negatif terhadap kepuasan kerja sebesar $(0,24)^{2}=$ $5,76 \%$. Sisanya, yaitu sebesar $94,24 \%$ dipengaruhi oleh diskrepansi aspek kepuasan kerja

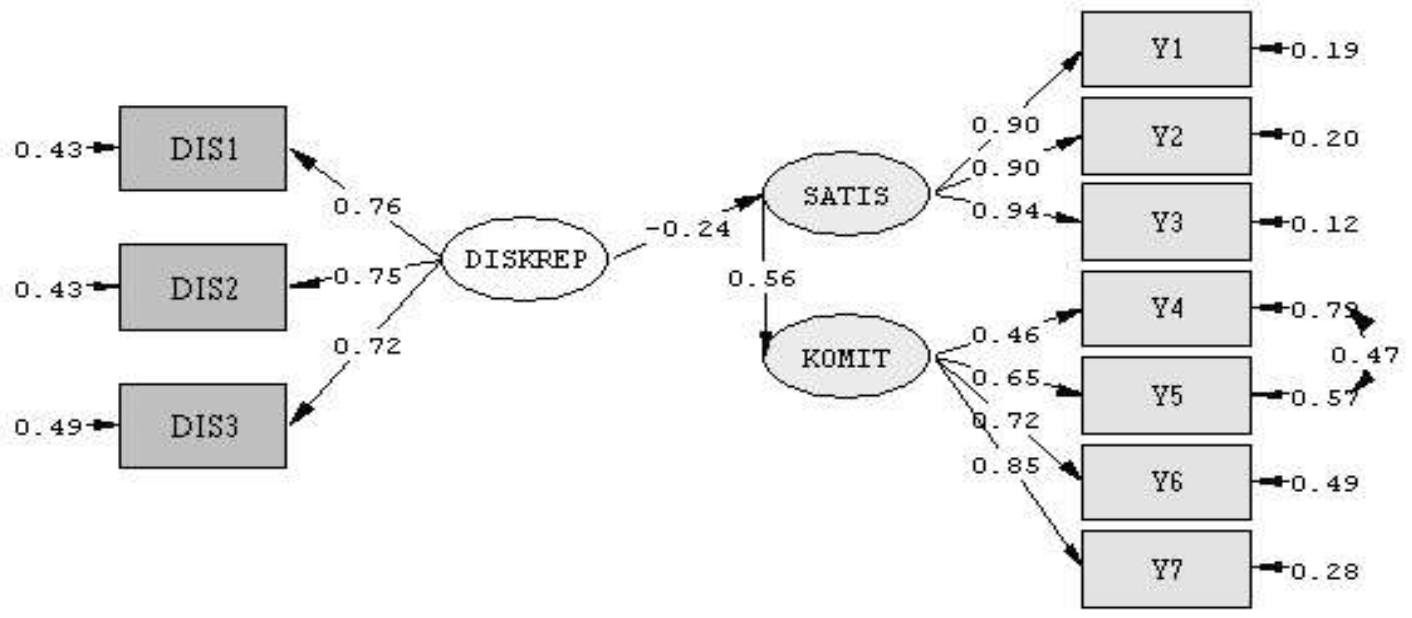

Chi-Square=118.32, $d f=32, P-v a l u e=0.00000$, RMSEA $=0.092$

Gambar 4. Diagram Jalur Lengkap Model Studi Mutu Kehidupan Kerja Guru Guru SD (Model II) 
yang lain. Walaupun pengaruh ini relatif kecil, namun signifikan. Hal ini ditunjukkan oleh perolehan nilai $t$ hitung sebesar 3,65>t tabel $(0,05)=1,97$. Diskrepansi harapan-persepsi pengembangan SDM ini dibentuk oleh tiga indikator (DIS1, DIS2, dan DIS3), yang pengaruhnya terhadap kepuasan kerja bervariasi. Hal ini dapat dilihat dari matriks korelasi berikut ini.

Correlation Matrix of ETA and KSI

\begin{tabular}{|l|r|r|l|l|l|}
\hline & SATIS & KOMIT & DIS1 & DIS2 & DIS3 \\
\hline SATIS & 1.00 & & & & \\
\hline KOMIT & 0.57 & 1.00 & & & \\
\hline DIS1 & -0.06 & -0.03 & 1.00 & & \\
\hline DIS2 & -0.18 & -0.10 & 0.59 & 1.00 & \\
\hline DIS3 & -0.32 & -0.18 & 0.54 & 0.52 & 1.00 \\
\hline
\end{tabular}

Berdasarkan matriks korelasinya, pengaruh yang paling besar disumbangkan oleh DIS3 (Kondisi kerja $=-0,32$ ), kemudian diikuti oleh DIS2 (pengembangan karir $=-0,18)$ ) dan urutan terakhir adalah DIS1 (kompensasi=-0,06). Hal ini menunjukkan betapa pentingnya indikator ini. Karena itu, temuan ini memperkuat pendapat Chamberlain dan Kindred (1976), lingkungan fisik sekolah berpengaruh cukup besar terhadap kepuasan kerja guru. Kondisi fisik sekolah yang buruk, gedung sekolah yang rusak dan kumuh tidak hanya berpengaruh terhadap kepuasan kerja, tetapi juga menurunkan moral kerja guru secara langsung (Corcoran,1988). Pengaruh diskrepansi harapan-persepsi pengembangan karir terhadap kepuasan kerja guru menempati urutan kedua. Hal ini sejalan dengan temuan Chapman et.al. (1993), yang melaporkan bahwa salah satu faktor yang mempengaruhi kepuasan kerja guru di negara-negara sedang berkembang adalah kesempatan untuk mengembangkan karir.

Pengaruh diskrepansi harapan-persepsi kompensasi terhadap kepuasan kerja guru menempati urutan ketiga. Hal ini sejalan pula dengan temuan Chapman (2000:30) yang melaporkan bahwa "teacher insentive can increase teachers job satisfaction and may help reduce teacher attrition as happier teachers choose to remain in teaching". Kompensasi guru tidak hanya meningkatkan kepuasan kerja, melainkan juga memungkinkan guru bertahan dalam profesinya.
Terdapatnya pengaruh negatif diskrepansi harapan-persepsi pengembangan/pemeliharaan SDM terhadap kepuasan kerja, memperkuat teori dikrepansi dari Porter (dalam Dahlan,1992). Berdasarkan persepsi seseorang, apabila yang didapatkan ternyata lebih kecil daripada yang diharapkan maka akan timbul ketidakpuasan. Sebaliknya, bila yang didapatkan lebih besar daripada yang diharapkan, akan muncul kepuasan. Dengan demikian besarnya diskrepansi atau diskonfirmasi akan menentukan tingkat kepuasan kerja guru. Diskrepansi yang tinggi merefleksikan bahwa keuntungan yang dirasakan dari pekerjaan masih relatif rendah jika dibandingkan dengan pengorbanan yang dikeluarkan. Hal ini sejalan dengan pendapat Fraser (1992:43) bahwa "kepuasan kerja akan muncul bilamana keuntungan yang dirasakan dari pekerjaannya melampaui biaya marginal yang dikeluarkannya". Temuan ini sejalan pula dengan konsep kepuasan pelanggan yang dikembangkan dalam manajamen kualitas total (TQM), khususnya yang diterapkan dalam bidang pendidikan (Sallis,1994). Salah satu konsep yang dikembangkan dalam TQM adalah kepuasan pelanggan dipengaruhi oleh nilai yang dirasakan pelanggan (costumer value). Nilai yang dirasakan pelanggan merupakan selisih maslahat total (total benefit) dengan pengorbanan total (total sacrifices) (Wahyuningsih, 2004:3). Selisih total maslahat dengan total pengorbanan, mencerminkan besarnya diskrepansi atau diskonfirmasi (disconfirmation). Implikasinya, guru sebagai pelanggan dalam (internal costumer), harus dipuaskan dengan memenuhi harapannya, sehingga nilai yang dirasakan dari pekerjaannya relatif besar.

Selain berpengaruh langsung terhadap kepuasan kerja total, variabel diskrepansi harapanpersepsi pengembangan SDM berpengaruh pula secara tidak langsung terhadap setiap indikator kepuasan kerja. Pengaruh tidak langsung terhadap indikator motivators, ambients dan hygienes, ditunjukkan oleh koefisien jalurnya masing-masing sebesar -0,216, -0,216, dan -0,226.

Mengapa pengaruhnya lebih besar terhadap indikator hygienes daripada kedua indikator lainnya? Hal ini sejalan dengan temuan sebelumnya bahwa variabel kepuasan kerja dalam penelitian ini, lebih banyak dibentuk oleh indikator 
hygienes. Hal ini ditunjukkan oleh besarnya koefisien taksiran bobot faktor dan reliabilitasnya.

Di sisi lain, diskrepansi harapan-persepsi pengembangan/pemeliharaan SDM memiliki pengaruh tidak langsung terhadap variabel komitmen guru, yang ditunjukkan oleh koefisien jalurnya sebesar -0,1344. Pengaruh tidak langsungnya terhadap indikator komitmen profesi, komitmen afektif, komitmen rasional, dan komitmen normatif, ditunjukkan oleh koefisien jalurnya masing-masing sebesar $-0,062,-0,087$, $-0,097$, dan -0,114. Berdasarkan angka-angka ini, pengaruh tidak langsungnya lebih besar terhadap indikator komitmen normatif.

Pengaruh negatif dari diskrepansi harapanpersepsi pengembangan/pemeliharaan SDM (dengan indikator kompensasi, pengembangan karir, dan kondisi kerja) terhadap komitmen guru, sejalan dengan temuan-temuan terdahulu. Dari indikator kompensasi, Kushman (1992) menemukan bahwa kompensasi berhubungan positif dengan komitmen guru. Dengan singkat ia menyimpulkan "school with more higly paid teachers had a tendency toward higher organizational commitment " (Kushman, 1992:19). Demikian juga temuan Chapman (2000). Dari indikator pengembangan karir, sejalan dengan temuan Kushman (1992), yang melaporkan bahwa pengembangan karir guru, berhubungan positif dengan komitmennya. Dari indikator kondisi kerja, relatif banyak temuan yang sejalan. MartinezPons (1990) menemukan bahwa terdapat hubungan negatif yang kuat antara kondisi fisik sekolah yang buruk dengan komitmen guru. Kondisi fisik sekolah yang buruk mencerminkan adanya diskrepansi harapan-persepsi kondisi kerja. Dari sisi persepsi, Kushman (1992), menemukan korelasi positif yang kuat antara kondisi fisik sekolah menurut persepsi guru, kepala sekolah, siswa, dengan komitmen guru. Demikian pula Firestone (1996) menemukan bahwa kondisi fisik sekolah yang adekuat, ternyata dapat meningkatkan kepuasan kerja dan komitmen guru.

Dengan demikian, dapat disimpulkan bahwa semakin rendah diskrepansi harapan-persepsi guru tentang pengembangan SDM, semakin baik pengaruhnya terhadap komitmen guru. Rendahnya tingkat diskrepansi ini, mencerminkan harapan guru terhadap indikator kompensasi, pengem- bangan karir, dan kondisi kerja dapat terpenuhi. Temuan ini sejalan dengan hasil penelitian Jusuf (1994), yang melaporkan bahwa realiasi harapan guru berhubungan positif dengan komitmen guru SD pada organisasinya. Semakin banyak harapan guru yang terwujud, makin tinggi komitmennya. Demikian pula temuan ini sejalan pula dengan hasil penelitian Seniati (2001), yang melaporkan bahwa diskrepansi harapan-persepsi karyawan terhadap pengelolaan SDM memberikan sumbangan yang bermakna terhadap komitmen normatif karyawan.

Dapat disimpulkan bahwa temuan di atas, memperkuat berlakunya teori diskrepansi (discrepancy theory), dan model kepuasan pelanggan dalam menjelaskan pengaruh kompensasi, pengembangan karir, dan kondisi kerja, terhadap kepuasan kerja guru. Dalam hal ini, apabila yang diperoleh lebih kecil dari yang diharapkan, cenderung menimbulkan ketidakpuasan dan sebaliknya. Secara implisit, temuan penelitian ini juga memperkuat berlakunya teori pemenuhan kebutuhan (need fulfilment theory), dan teori keadilan (equity theory). Dalam hal ini, kepuasan kerja guru tergantung pada terpenuhi atau tidaknya kebutuhan serta ada atau tidaknya keadilan dalam suatu situasi kerja.

Hasil pengujian hipotesis kedua, menunjukkan bahwa kepuasan kerja berpengaruh positif terhadap komitmen guru sebesar $(0,56)^{2}=$ $31,36 \%$ sisanya sebesar $68,64 \%$ dipengaruhi oleh variabel lain. Pengaruhnya sangat signifikan, ditunjukkan oleh nilai $\mathrm{t}$ hitung sebesar 8,21 > t tabel $(0,005)=1,97$. Pengaruh tidak langsungnya terhadap indikator komitmen profesi, komitmen afektif, komitmen rasional, dan komitmen normatif, ditunjukkan oleh koefisien jalurnya masing-masing sebesar 0,2576, 0,364, 0,4032, dan 0,476.

Mengapa pengaruhnya lebih besar terhadap komitmen normatif daripada ketiga indikator lainnya. Hal ini sejalan dengan temuan sebelumnya, bahwa variabel komitmen guru dalam penelitian ini lebih banyak dibentuk oleh indikator komitmen normatif. Hal ini ditunjukkan oleh besarnya koefisien taksiran bobot faktor dan reliabilitasnya.

Karena itu tidak mengherankan jika Chapman et.al (1993) melaporkan bahwa di negara-negara sedang berkembang, kepuasan kerja guru, 
khususnya kepuasan karir merupakan salah satu faktor yang menjadi pertimbangan guru apakah ia akan tetap bertahan atau meninggal-kan profesinya. Bertitik tolak dari hal tersebut, temuan ini memperkuat teori dari Davis \& Newstrom (2003), tentang model hubungan kinerja, kepuasan kerja, dan komitmen sebagai-mana telah dikemukakan dalam landasan teori.

Kepuasan kerja berpengaruh terhadap masing-masing indikator komitmen sejalan dengan temuan terdahulu. Thomas (dalam Seniati, 2001), melaporkan bahwa terdapat hubungan antara dimensi kepuasan kerja dengan dimensi komitmen organisasi. Dalam penelitian ini pengaruhnya untuk masing-masing indikator komitmen relatif kecil (di bawah $25 \%$ ). Hal ini disebabkan: 1) sesuai model penelitian, pengaruhnya bersifat tidak langsung; 2) terdapat variabel moderator lain, yang berkaitan dengan nilai kerja (work values) yang tidak dimasukkan dalam model penelitian ini. Etika kerja merupakan keyakinan yang memandang pentingnya kerja keras (hard work). Dalam hal ini kerja keras dan dedikasi terhadap pekerjaan merupakan karakteristik manusia yang sangat dihargai. Hal ini akan mempengaruhi komitmen, sebab salah satu indikator yang harus ada dalam komitmen adalah "kemauan untuk bekerja keras demi kepentingan organisasi".

Keterlibatan kerja merupakan suatu derajat yang memperlihatkan sejauh mana memihak pada pekerjaannya, dan berpartisipasi aktif di dalamnya, serta menganggap kinerjanya penting bagi harga diri (Robbins, 1996:170). Hal ini terlihat dari keseriusannya dalam melakukan pekerjaan, dan memiliki nilai-nilai penting yang selalu dipertahankan dalam melakukan pekerjaan. Karena berkaitan dengan nilai kerja (work values), variabel ini pun mempengaruhi komitmen.

Dapat disimpulkan bahwa temuan penelitian di atas memperkuat berlakunya model hubungan kepuasan kerja dan komitmen dalam kajian perilaku organisasi, dan model kepuasan pelanggan di mana kepuasan kerja berfungsi sebagai prediktor bagi loyalitas/komitmen guru. Model hubungan ini mengimplikasikan bahwa untuk meningkatkan loyalitas/komitmen guru (komitmen profesi dan komitmen organisasi) diperlukan peningkatan kepuasan kerja.
Hasil pengujian model penelitian dengan dikontrol variabel jender, usia, masa kerja, dan tingkat pendidikan menunjukkan bahwa: 1) Dilihat dari variabel gender, model efektif bagi kelompok sampel guru maupun kelompok wanita. Namun, dilihat dari besarnya koefisien jalur, model lebih efektif untuk kelompok sampel pria; 2) Dilihat dari variabel usia, model lebih efektif bagi kelompok sampel guru yang usianya di bawah 40 tahun; 3) Dilihat dari variabel masa kerja, model lebih efektif bagi kelompok sampel guru yang masa kerjanya kurang dari 20 tahun; dan 4) Dilihat dari variabel tingkat pendidikan, model lebih efektif bagi kelompok sampel guru yang berpendidikan di bawah S1 (SLTA/D2).

\section{Simpulan dan Saran}

\section{Simpulan}

Tinggi rendahnya kepuasan kerja guru SD dipengaruhi oleh besar kecilnya diskrepansi harapan-persepsi pengembangan/pemeliharaan SDM (diskrepansi harapan-persepsi kompensasi, dikrepansi harapan-persepsi pengembangan karir, dan diksrepansi harapan-persepsi kondisi kerja. Diskrepansi harapan-persepsi yang paling besar pengaruhnya terhadap kepuasan ialah kondisi kerja (DIS 3) kemudian dikuti pengembangan karir (DIS 2) dan paling kecil pengaruhnya ialah kompensasi (DIS1). Diskrepansi harapanpersepsi pengembangan/pemeliharaan SDM juga berpengaruh secara tidak langsung terhadap setiap faktor kepuasan kerja (pemotivasian, ambients, dan pemeliharaan). Pengaruh tidak langsung yang paling besar ialah terhadap faktor pemeliharaan. Secara umum, dapat disimpulkan bahwa semakin rendah diskrepansi harapanpersepsi pengembangan/pemeliharaan SDM, semakin tinggi tingkat kepuasan kerja guru.

Tinggi rendahnya komitmen guru SD dipengaruhi secara tidak langsung oleh besar kecilnya diskrepansi harapan-persepsi pengembangan SDM. Diskrepansi harapan-persepsi pengembangan SDM juga berpengaruh tidak langsung terhadap setiap faktor komitmen guru. Pengaruh tidak langsung yang paling besar ialah terhadap komitmen normatif. Secara umum, dapat disimpulkan bahwa semakin rendah tingkat diskrepansi pengembangan/pemeliharaan SDM, 
semakin tinggi keterikatan guru dengan pekerjaan dan sekolahnya.

Komitmen guru SD dipengaruhi secara langsung oleh kepuasan kerjanya. Demikian pula kepuasan kerja berpengaruh secara tidak langsung terhadap setiap faktor komitmen guru (komitmen profesi, komitmen afektif, komitmen rasional, dan komitmen normatif). Pengaruh tidak langsung yang paling besar ialah terhadap komitmen normatif. Secara umum dapat disimpulkan bahwa semakin tinggi tingkat kepuasan kerja guru, semakin tinggi keterikatan guru dengan pekerjaan dan sekolahnya.

Dilihat dari variabel kontrol, (jender, usia, masa kerja, dan pendidikan) model penelitian ini lebih efektif bagi guru SD berjenis kelamin pria maupun wanita, usia di bawah 40 tahun, masa kerja di bawah 20 tahun, dan pendidikan di bawah S1. Kelompok sampel yang usianya di bawah 40 tahun, masa kerjanya kurang dari 20 tahun dan pendidikannya di bawah S1 lebih tinggi tingkat kepuasan dan komitmennya. Selain itu, terdapat kecenderungan, bahwa usia dan masa kerja tidak berpengaruh terhadap kepuasan kerja guru.

\section{Saran}

\section{Saran Untuk Pemerintah Pusat}

Berbagai bentuk perundang-undangan pendidikan yang telah dihasilkan seperti UndangUndang Guru dan Dosen sebagai sarana untuk mengembangkan guru sebagai profesi yang bermartabat, maka Pemerintah perlu segera ditindaklanjuti dan dilaksanakan secara konsekuen.

\section{Saran Untuk Pemerintah Daerah (Dinas Pendidikan)}

Pertama, diharapkan memberikan tunjangan daerah, dan insentif lainnya secara layak sebagai bentuk peningkatan kesejahteraan guru, yang dilakukan sesuai dengan kemampuan keuangan pemerintah daerah. Kedua, pemerintah daerah diharapkan dapat menciptakan sistem pengembangan karir guru, antara lain sistem promosi dan sistem kenaikkan pangkat secara efektif, sehingga dapat memenuhi harapan para guru. Selanjutnya, jabatan kepala sekolah sebagai tugas tambahan, perlu dibatasi hanya sampai dua periode (dikenal dengan istilah periodesasi), sehingga terbuka kesempatan atau kepada guru lainnya untuk menduduki jabatan kepala sekolah. Ketiga, pemerintah daerah diharapkan dapat menciptakan sistem peningkatan kemampuan profesional para guru sehingga dapat mencapai standar kualifikasi minimum. Peningkatan kemampuan guru, dapat dilakukan dengan memfasilitasi (memberikan bantuan biaya) studi lanjut guru-guru yang belum berkualifikasi Strata 1 , sehingga dapat mencapai kualifikasi minimum yang disyaratkan dalam Undang-Undang Guru dan Dosen. Disamping itu pelatihan-pelatihan dilakukan secara periodik dan teratur bekerja sama dengan pihak-pihak terkait seperti Lembaga Penjamin Mutu Pendidikan (LPMP \& P4TK). Keempat, melaksanakan ketentuan standar sarana dan prasarana yang telah digariskan di dalam rambu-rambu Standar Nasional Pendidikan, yang berisikan kriteria minimal tentang ruang belajar, perpustakaan, laboratorium, tempat ibadah, dan sumber belajar lain yang diperlukan untuk menunjang proses pembelajaran

\section{Saran Untuk Kepala Sekolah}

Mengacu pada temuan penelitian, dapat diajukan saran sebagai berikut. Pertama, perlu mengupayakan peningkatan kesejahteraan guru melalui berbagai cara, antara lain mengalokasikan anggaran sekolah untuk insentif guru yang diberikan berdasarkan pertimbangan kinerja. Kedua, dalam hal pengembangan karir guru, kepala sekolah harus memfasilitasi dan memberikan kesempatan seluas-luasnya kepada guru untuk mengembangkan karirnya (kenaikkan pangkat, promosi), termasuk kesempatan untuk mengembangkan kemampuannya dengan cara mengikuti pendidikan lebih lanjut, dan mengikuti pelatihan/penataran. Ketiga, dalam hal kondisi kerja, kepala sekolah harus berupaya menciptakan lingkungan fisik sekolah yang layak, sehat, bersih dan menyenangkan. Tidak kurang pentingnya ialah menyediakan sarana/perlengkapan yang memadai untuk kepentingan proses belajarmengajar. 


\section{Pustaka Acuan}

Amstrong, Michael. 2003. Manajemen Sumber Daya Manusia (terjemahan Ati Cahyani). Jakarta: Bhuana Ilmu Populer.

Beatty, W. Richard, dan Schneiner Eric. 1992. Personnel Administration, Massachusetts: Addison Wesley Publishing Company

Bowin, R.B. dan Harvey, Don. 1996. Human Resources Management An Experiential Approach. London: Prentice-Hall International, Inc.

Cascio, W.F. 1998. Managing Human Resources. New York: McGraw Hill, Inc.

Chamberlain, L. dan Kindred, Leslie. 1976. The Teacher and School Organization. New Jersey: PrenticeHall Inc.

Chapman, David. 2000. Management and Eficiency in Education. Hongkong: Comparative Education Research Centre, The University of Hongkong.

Chapman, David., Conrad W. Snyder, and Shirley A. Burchfield. 1993. "Teacher Incentives in The Third Word" Journal of Teacher \& Teacher Education, 9, (3), 301-316

Corcoran, T.B. 1988. Working in Urban School.Washington: Institute for Educational Leadership

Dahlan, Dadang. dan Tantra, Ketut. 1992. Kepuasan Kerja Guru SMA di Bali. Laporan Penelitian. Singaraja: FKIP Universitas Udayana.

Davis, Keith dan Newstrom, Jhon. W. 2003. Perilaku Dalam Organisasi (Alih Bahasa Agus Dharma). Jakarta: PT Erlangga

Dubrin, Andrew, J. 1994. Human Relations A Job Oriented Approach, Virginia: Reston Publishing Company, Inc.

Feldman, D.C, dan Arnold, H.J. 1986. Managing Individual and Group Behavior in Organization. New York: McGraw-Hill, Inc.

Firestone, W.A., dan Pennel, J.R. 1993. "Teacher Commitment, Working Conditions, and Differential Incentives Policies". Journal of Review Educational Research. 63, 489-525.

Firestone, W.A. 1996. "Redesigning Teacher Salary Systems for Educational Reform". Journal of Educational Administration Quarterly, 31, (3), 549-574.

Fraser, T.M. 1992. Stres \& Kepuasan Kerja. Jakarta: PT Pustaka Binaman Pressindo.

Gaffar, M.F. 1987. Perencanaan Pendidikan: Teori dan Metodologi. Jakarta: Depdikbud.

Handoko, H. 1996. Manajemen Personalia dan Sumberdaya Manusia. Yogyakarta: BPFE.

Jalal, Fasli., dan Supriadi (editor). 2001. Reformasi Pendidikan Dalam Konteks Otonomi Daerah. Yogyakarta: Adicita.

Jusuf, Ina. M.F. 1994. Keikatan Guru Sekolah Dasar Pada Organisasi: Suatu Kajian Tentang Hubungan Karakteristik Pribadi, Karakteristik Peran, Lingkungan Pekerjaan dengan Keikatan pada Organisasi, dan Kaitannya dengan Niat Meninggalkan Organisasi. Tesis Pasca Sarjana Psikologi, pada PPS Universitas Indonesia: tidak diterbitkan.

Kaplan, Robert dan Norton, David. 2000. .Balanced Scorecard (Edisi terjemahan). Jakarta: Erlangga

Kushman, James. W. 1992. "The Organizational Dynamic of Teacher Workplace Commitment" Journal of Educational Administration Quarterly. 28,(1), 5-42.

Kuzmic, J. 1994. "A Beginning Teacher's Search for Meaning: Teacher Sosialization, Organizational Literacy, and Empowerment". Journal of Teaching and Teacher Education, 10 (1), 15-27.

Lawler, Edward. 1992. The Ultimate Advantage: Creating The High Involvement Organization. San Francisco: Josssey-Bass.

Mangkunegara, A.P. 1995. Psikologi Perusahaan. Bandung: Trigenda Karya 
Martinez Pons, M. 1990. "Test of a three Model of Teacher Commitment". Journal of Educational Administration Quarterly. 28, (1), 5-42

Minner, J.B. dan Mary Green Miner, 1987. Personnel \& Industrial Relatins: A Managerial Approach. New York: Mac Millan Publishing Co. Inc.

Noe, Raymond A., Jhon R. Hollenbeck, Barry Gehart, and Patrick. 2003. Human Resources Management. New York: McGrawHill

Ostroff, C. 1992. "The Relationship Between Satisfaction, Attitudes, and Performance", Journal of Applied Pschology. 77, 963-974

Pidarta, Made. 2004. Manajemen Pendidikan Indonesia. Jakarta: Rineka Cipta

Rangkuman Data Sekolah Dasar Negeri dan Swasta Kabupaten Bandung. 2004. Bandung: Dinas Pendidikan, Pemerintah Daerah Kabupaten Bandung.

Robbins, Stephen P. 1996. Teori Organisasi: Struktur, Desain, dan Aplikasi. (Alih Bahasa Jusuf Udayana). Jakarta: Penerbit Arcan

Salis, Edward. 1994. Total Quality Management in Education. London: Kogan Page Educational Management Series.

Sastradipoera, Komaruddin. 2002. Manajemen Sumber Daya Manusia. Bandung: Kappa Sigma

Sayogyani. 2002. "Memulihkan Profesi Guru" Kedaulatan Rakyat (Juni 2002)

Schargel, Franklin, P. 1994. Transforming Education Through Total Quality Management. Princeton: Education Princeton Junction

Schuler, Randal., and Jackson Susan. 1992. Human Resources Management in Australia. Harper Educational Pty. Ltd

Seniati, Ali. Nina. 2001. "Hubungan Antara Persepsi dan Diskrepansi Harapan-Persepsi Karyawan Atas Pengelolaan SDM Dengan Komitmen Karyawan Pada Organisasi" Jurnal Manajemen dan Usahawan Indonesia. 01 (5).

Sevilla, Consuelo G., Jesus A. Ochave, Twila G. Punsalan, Bellla P. Regala. 1993. Pengantar Metode Penelitian. Jakarta: UI Press

Sidi, Indra Djati. 2001. Menuju Masyarakat Belajar: Menggagas Paradigma Baru Pendidikan. Jakarta: Radar Jaya.

Silvestro, Rhian. 2002. "Dispelling the Modern Myte: Employee Satisfaction and Loyalty Drive Service Profitability" International Journal of Operation \& Production Management. 22, 30-49

Snyder, S., C. Head, and P. Sorenson. 1994. Vision, Values and Courage: Leadership for Quality Management. New York: The Free Press

Steers, Richard. 1987. Organizational Effectiveness. California: Goodyears Publishing Company.

Susanto, A.B. 1997. Manajemen Aktual. Jakarta: PT Gramedia Widiasarana

Surya, Mohammad. 2000. "Aspirasi Peningkatan Kemampuan Profesional dan Kesejahteraan Guru". Jurnal Pendidikan dan Kebudayaan. 021

Tjiptono, Fandy. 1997. Prinsip-Prinsip Total Quality Service. Yogyakarta: Andi

Veithzal, Rivai. 2004. Manajemen Sumber Daya Manusia Untuk Perusahaan: Dari Teori ke Praktek. Jakarta: PT Raja Grafindo Persada.

Wahyuningsih. 2004. "Costumer Value: Concept, Operationalization, and Outcome". Jurnal Manajemen dan Usahawan Indonesia. 08.

Werther, J. W. dan Davis, Keith. 1996. Human Resources Management. New York: McGraw-Hill. 